\title{
Dies Process Performance Improvement Maintenance With e-DMIS Based on IoT Technology
}

\author{
Adi Rusdi Widya*1, Ikhsan Romli ${ }^{2}$ \\ Pelita Bangsa University, Jl. Inspeksi Kalimalang Tegal Danas Arah Deltamas, Cikarang Selatan, \\ Bekasi, (021) 2851-8181 \\ E-mail : adirusdiw@pelitabangsa.ac.id*1,ikhsan.romli@pelitabangsa.ac.id ${ }^{2}$ \\ *Corresponding author
}

\begin{abstract}
Improvement between departments within the company requires a mutually supportive system so that cooperation occurs between interrelated departments. This requires effort and commitment that needs to be supported by related shareholders so that the occurrence of lost time during the production process can be minimized so that the planned time runs effectively and efficiently in increasing productivity. The difficulty in supervising and controlling the production process is the reason for knowing the abnormality in the process of replacing the dies and controlling the process of replacing printing equipment or dies for the Stamping process still using a manual system and the process recording system still using paper that is prone to lose and is engineered irresponsibly. The method used to create an electronic Dies replacement monitoring system by collecting problem data, comparing manual systems with several experiments and testing tools, using loT in the form of PLC, HDMI as a tool for online communication. The DIMS monitoring system can be used to monitor and provide initial information when there is a request for the Dies replacement process so that replacement requests and needs in the process can be carried out immediately because they can be detected early.
\end{abstract}

Keywords - Dies, PLC, DMIS, loT, HMI

\section{INTRODUCTION}

The development of loT-based monitoring tools is needed to support the performance of a company in carrying out organizational targets, support and cooperation between industry and academics are needed to support each other between the two, so that collaboration is established that realizes sustainable innovation, this research is based on a case faced by a supplier manufacturing industry. a part of the automotive industry. The purpose of this research is to help speed up information on the condition of Equipment and Dies Part replacement processes in the production process in real-time and accurately. The utilization of computers and applications that can support the work provides more value in supporting the process of monitoring the abnormality of the process. Implementation of the Dies Maintenance Information System (DMIS) is needed to provide information on the needs of the production process.

In the modular structured Smart Factories of Industry 4.0, CPS monitors physical processes, creates virtual copies of the physical world, and makes decentralized decisions. Through IOT, CPS communicate and cooperate with each other and with humans in real-time [1]. The Industrial Internet of things (IIOT) has been introduced to the energy industry and all assets in the distributed energy system are treated as smart industrial devices so that similar industrial distributed control can be applied. which is much faster than a normal network [2]. 
As a real-time option of the Open Platform Communication Unified Architecture discussed Time Sensitive Network which in the OPC UA connection may meet the real-time, openness, virtual, safety, security features of the appropriate common communication channel in the store as well as on the top floor of the architecture factory control [3]. One way to realize this situation is to involve the operator in the inspection task. This is because the operators are familiar with the operation of the machine. After all, they have been operating the machine for a long period. Operators should be assigned minor inspection tasks based on their safety measures. This can be done through the implementation of the Autonomous Maintenance (AM) program [4].

The main challenge in implementing AM practice is changing the mindset, habits, and culture of operators, technicians, and engineers in taking responsibility when given certain tasks. The challenge ahead is to apply the same AM practice module (AM framework) to other production lines to improve machine/equipment performance i.e. minimize machine breakdown before starting long-term TPM planning. Another possible area of research in the future is the integration of TPM with other, more technical maintenance techniques, such as time-based maintenance, condition-based maintenance, and risk-based maintenance [5].

The main purpose of the Poka-Yoke concept is to make the whole system fault proof which means no one can make a mistake even if one wants to stop making mistakes on purpose. It eliminates defects or errors. The term was coined by Shigeo Shingo in the 1960s as part of the Toyota Production System. The goal of a Poka-yoke is to design processes so that errors can be detected and corrected immediately, eliminating damage at the source. Countermeasures consisting of three steps of risk analysis to be managed:

1. Identify needs

2. Identify possible errors

3. Error management before meeting needs.

These steps are considered when thinking about implementing Poka-Yoke [6].

A successful Poka-yoke results in increased productivity with less waste (rework waste, scrap) because we believe in product quality, as faults are blocked at the source itself. There may be some practical limitations in the poka-yoke but we must overcome all of them to achieve the goal of "Zero Defect, Zero Waste, and Zero Delay". In one sentence the poka-yoke is launching preventive actions for systematic movement on the QMS success ladder with higher levels of system performance and productivity with high-quality products at minimum costs [7].

Poka-Yoke is one of the most important tools in TQM (total quality management). The efficacious poka-yoke results in increased productivity with less waste (rework waste, scrap) because we believe in product quality, as faults are blocked at the source itself. There may be practical limitations in the poka-yoke but we manufacture "Fault, Waste \& Delay" products all of which have to be addressed, increasing productivity with minimum waste (waste due to rework, scrap) because we believe in product quality, as faults are blocked at their source. There may be practical limitations in the poka-yoke but we manufacture "Fault, Waste \& Delay" products which all have to overcome all of them to achieve the goal of zero. In one decision Poka-yoke (Error proofing) launched preventive measures for systematic movement on the QMS success ladder with higher levels of system performance and productivity with high-quality products at minimum cost [8].

Training on various Human Factors such as staying focused, doing due diligence, a sound mind should be facilitated by the manager. While no method is guaranteed to prevent human error, avoiding stress and staying focused by drinking coffee are the most commonly used everyday methods and practices available to all. As defined at the outset of this study, human error is usually the result of a long chain of events, and preventing human error in the workplace requires different types of precautions [9]. 
SCADA is used in industries that require remote monitoring and control with a large number of inputs/outputs. In general, the SCADA system consists of [10]:

1. Human Machine Interface (HMI).

2. Remote terminal unit connecting some measurement sensors used in factories and others.

3. Computer-based surveillance system as data collector.

4. Communication infrastructure that connects remote terminal units with the surveillance system.

5. Programmable Logic Controls

SCADA is just a precursor to IloT mainly because SCADA systems have evolved to connect to the internet but lack the analytics and level of connectivity found in IloT [11].

The FPIS design will take into account the basics \& functions of the HMI such as:

1. An independent HMI / SCADA system through the use of a network-based database or more web-based can be used as a solution to work in a single monitoring system.

2. For the design of the proposed study object, the speed of access through the database is still very slow. So it's only suitable for systems working with response under 1s [12].

The resulting output will follow product quality and must be supplemented with data, FPIS raises awareness of machine maintenance capabilities and real-time conditions, a systematic framework for assessing information quality in data-driven empirical studies. This is the missing piece in most data analytics efforts, which we believe can bring further insights and contribute significantly to increasing their effectiveness. The proposed framework can be used to plan and optimize the implementation of data-based activities in Industry 4.0. Assess the quality of information generated in data-based empirical studies.

Research by Wiranto, et al. in 2015 [13] designed a continuous water quality monitoring system consisting of sensors to measure Dissolved Oxygen (DO) and $\mathrm{pH}$, PCDuino microcontroller-based data acquisition, sample collection unit, and PC-based graphical display. Experimental results show that when the measured DO value falls below $5 \mathrm{mg} / \mathrm{l}$, or the $\mathrm{pH}$ value is below 4 or above 9 , the sample collection unit works by filling $20 \mathrm{ml}$ of the sample in less than $650 \mathrm{~ms}$. The results show that all measured water quality parameters can be successfully transmitted and displayed in real-time by the software interface. All measured data can be displayed on a PC for further analysis.

Research conducted on the Internet of Things-Based Remote Monitoring System using the MQTT Protocol has been carried out by Budioko in 2016 [14], in which the implementation of this system uses the LM35 temperature sensor, Arduino UNO, and the Esp8266 ver 01 wifi module. The system prototype has been successfully realized on the Sensor Node as well as Monitor Nodes. Based on the test results, the system can connect to both local MQTT servers and global MQTT servers, able to send data (publish) and receive data (subscribe).

Then, in 2017 a research is conducted by Khatri, et al. [15] shows that the use of a Wi-Fi shield for wireless communication is applied as a device system to build a small network of wireless sensors. Energy savings are very significant by using this system. The central system equipped with computer-based programming modules can be used with most of the popular Android mobile devices which are directly connected to increase the overall system convenience and timeliness. This study describes a smart solution to control water quality through its $\mathrm{pH}$, treat municipal wastewater and reuse it for agricultural and gardening purposes. The result of this research is the design and development of a low-cost monitoring tool using an electronic system and its application with maintained quality (monitoring and controlling) for water quality within the specified standard. 
Research conducted by Widya \& Syaputra in 2018 [16] in which Raspberry-Pi, Arduino Wemos-D1 are one of the tools for developing and designing a machine monitoring system (MMS) used for machine status monitoring systems (running/stop), Raspberry-Pi functions as Programmable Logic Controller (PLC-master controller) and Arduino Wemos-D1 as slaves that are integrated directly with the machine. Communication between the two uses wireless. The Human Machine Interface (HMI) for monitoring this system is web-based so that it can be accessed via a browser. The results of this development can be used to find out machine abnormalities in real-time $\&$ online so that machine damage information can be responded to quickly by maintenance/machine repair officers.

Research conducted by Rishitha, 2019 [17] regarding the Design of "IoT based Automation in Domestic Sewage Treatment Plant to Optimize Water Quality and Power Consumption" where this research was conducted to make waste treatment more effective and cheaper by utilizing IOT to reduce power consumption and provide water which is of higher quality and can be used for further use. The final result of the research is to create a tool that can provide information on the quality of water from wastewater treatment through an loTbased Sewage Treatment Plant (STP) so that the need for operators to monitor is no longer needed, users/users get the correct information data and can save the previous process recording data.

Research conducted by Zakaria Yahouni, Nasser Mebarki, 2017 [19] regarding the design "A new HMI scheduling model implemented on a real manufacturing scheduling system" The experiments conducted on an emulation program using three decision-aid criteria showed the usability of the proposed $\mathrm{HMI}$, The particularity of the second scenario relies on representations on the HMI model to help the decision-maker having a farsighted overview on the perturbation impact and therefore taking better decisions.

In table 1 . as a literature review conducted previously by researchers to facilitate as a reference for further research as follows:

Tabel 1. Previous Research (literature Review)

\begin{tabular}{|c|c|c|c|c|c|c|c|}
\hline \multicolumn{2}{|c|}{ Literature } & \multicolumn{3}{|c|}{ Research Background } & \multicolumn{2}{|c|}{$\begin{array}{l}\text { Research Design and } \\
\text { Methodology }\end{array}$} & \multirow{2}{*}{ Discussion } \\
\hline Author & Year & Problems & Purpose & $\begin{array}{c}\text { Scope \& } \\
\text { Limitation }\end{array}$ & Methode & Findings & \\
\hline $\begin{array}{l}\text { H. H. B. } \\
\text { Boyes, J. } \\
\text { Cunningham } \\
\text { dan T. } \\
\text { Watson }\end{array}$ & Dec-18 & $\begin{array}{l}\text { concepts such } \\
\text { as cyber- } \\
\text { physical } \\
\text { systems }\end{array}$ & $\begin{array}{l}\text { Develops an } \\
\text { analysis } \\
\text { framework } \\
\text { for lloT that }\end{array}$ & $\begin{array}{l}\text { Identifying } \\
\text { some gaps in } \\
\text { the literature. }\end{array}$ & $\begin{array}{l}\text { The paper } \\
\text { develops a } \\
\text { definition of } \\
\text { IloT and } \\
\text { analyses related } \\
\text { to partial loT } \\
\text { taxonomies. }\end{array}$ & $\begin{array}{l}\text { concludes by } \\
\text { identifying } \\
\text { some gaps in } \\
\text { the literature. }\end{array}$ & $\begin{array}{l}\text { Further research is } \\
\text { required to consider } \\
\text { the implications of } \\
\text { installing lloT devices } \\
\text { in an operational } \\
\text { architecture }\end{array}$ \\
\hline $\begin{array}{l}\text { K. } \\
\text { Alexopoulos, } \\
\text { S. Koukas, N. } \\
\text { Boli dan D. } \\
\text { Mourtzis }\end{array}$ & Jul-18 & $\begin{array}{l}\text { technological } \\
\text { revolution in } \\
\text { information } \\
\text { and } \\
\text { communication } \\
\text { technology. } \\
\text { Manufacturing }\end{array}$ & $\begin{array}{l}\text { The purpose } \\
\text { of this paper } \\
\text { is to present } \\
\text { the } \\
\text { architecture } \\
\text { and } \\
\text { the } \\
\text { development }\end{array}$ & $\begin{array}{l}\text { IPSS that } \\
\text { features a } \\
\text { service for laser } \\
\text { machine data } \\
\text { analysis and } \\
\text { aggregation }\end{array}$ & $\begin{array}{l}\text { A fully } \\
\text { functional } \\
\text { prototype of } \\
\text { the IloT } \\
\text { framework } \\
\text { together } \\
\text { with an IPSS } \\
\text { system }\end{array}$ & $\begin{array}{l}\text { General } \\
\text { Electric } \\
\text { provides a } \\
\text { framework } \\
\text { named } \\
\text { PREDIX }\end{array}$ & $\begin{array}{l}\text { The present work } \\
\text { provides architecture, } \\
\text { development } \\
\text { of an lloT framework } \\
\text { for realizing }\end{array}$ \\
\hline
\end{tabular}




\begin{tabular}{|c|c|c|c|c|c|c|c|}
\hline $\begin{array}{l}\text { H. Ab- } \\
\text { Samat, W. } \\
\text { Liau, W. Yap, } \\
\text { S. } \\
\text { Kamaruddin, } \\
\text { H. Tan dan } \\
\text { P. Khoe }\end{array}$ & Nov-12 & $\begin{array}{l}\text { investigate the } \\
\text { performance of } \\
\text { maintenance } \\
\text { system }\end{array}$ & $\begin{array}{l}\text { Technicians } \\
\text { work is } \\
\text { reduced with } \\
\text { the aid of } \\
\text { operators }\end{array}$ & $\begin{array}{l}\text { Some } \\
\text { complications } \\
\text { need to be } \\
\text { solved by } \\
\text { implementing } \\
\text { the AM }\end{array}$ & $\begin{array}{l}\text { Autonomous } \\
\text { Maintenance } \\
\text { (AM) program }\end{array}$ & $\begin{array}{l}\text { implemented } \\
\text { in a case } \\
\text { study } \\
\text { company as a } \\
\text { verification } \\
\text { and validation } \\
\text { processes }\end{array}$ & $\begin{array}{l}\text { checking methods that } \\
\text { the operators use is } \\
\text { correct to avoid } \\
\text { checking error on the } \\
\text { component. }\end{array}$ \\
\hline V. Shenoy, & Oct-18 & $\begin{array}{l}\text { The factual } \\
\text { reason for this } \\
\text { is that any } \\
\text { workplace } \\
\text { mistake }\end{array}$ & $\begin{array}{l}\text { mistake } \\
\text { prevention } \\
\text { plan for } \\
\text { avoiding } \\
\text { workplace }\end{array}$ & $\begin{array}{l}\text { Based on the } \\
\text { above analysis } \\
\text { and } \\
\text { interpretation } \\
\text { of mistake- } \\
\text { proofing } \\
\text { methodologies }\end{array}$ & $\begin{array}{l}\text { Error proofing } \\
\text { analysis }\end{array}$ & $\begin{array}{l}\text { the factors for } \\
\text { control a } \\
\text { staff's } \\
\text { psychological } \\
\text { mind } \\
\text { physically }\end{array}$ & $\begin{array}{l}\text { Pieces of training on } \\
\text { various Human Factors } \\
\text { like staying focused } \\
\text { making due diligence }\end{array}$ \\
\hline
\end{tabular}

From several previous related studies, this research is to apply loT by connecting PLC control, Wemos Sensors, and HMI Signals to design a monitoring system in real-time and online and at low cost, so the purpose of the design that the author will do with the theme "Dies Process Performance Improvement Maintenance With e-DMIS Based on IoT Technology " can be applied with the aim of helping the user to prevent abnormal production processes and increase user effectiveness in carrying out the monitoring process and improving production process performance in real-time and online The design concept of the DMIS can be seen as shown in Figure 1 as below:

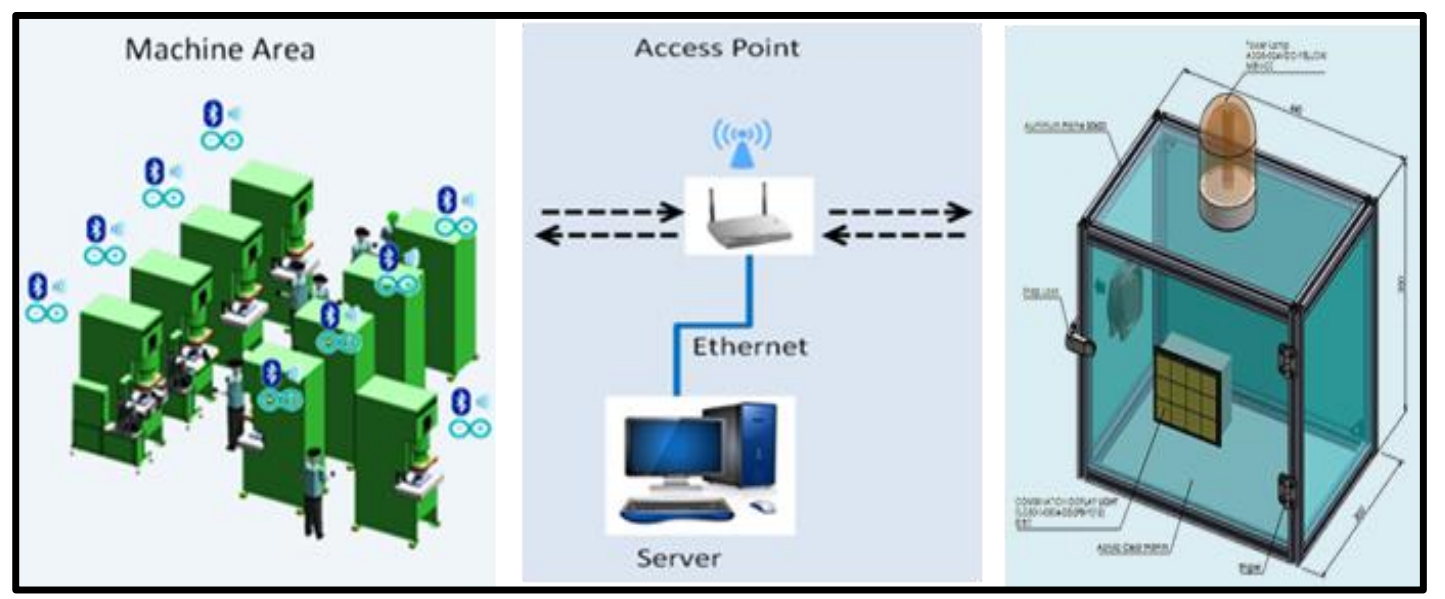

Figure 1. Design Concept DMIS

\section{RESEARCH METHOD}

The research stage begins with library research, looking for references, designing the system and determining the components to be used, making hardware prototypes, creating programs, and conducting testing. The flow chart of the research stages as shown in the figure, the details of the research flow can be seen as follows: The research stage begins with literature study, looking for references, designing the system and determining the components to be used, making hardware prototypes, making programs, and conducting testing. The flow chart of the research stages as shown in Figure 2, the details of the research flow can be seen as follows: 


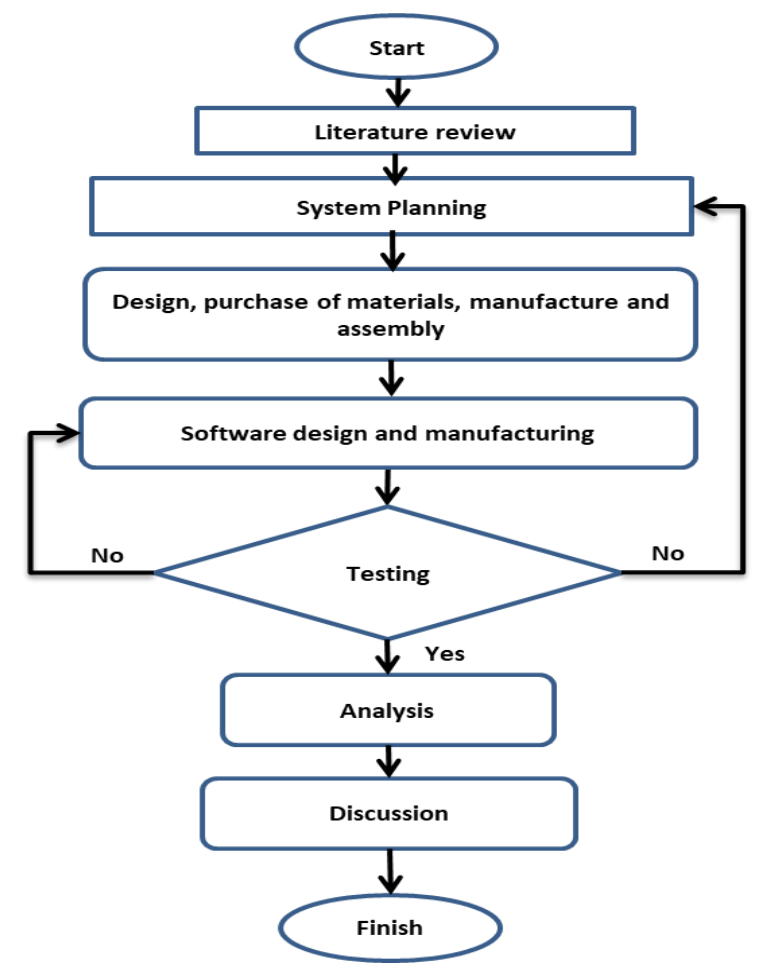

Figure 2. Flow of Research

Explanation of Research Steps:

Step 1: Literature study by searching and reading some literature, journals about machine monitoring, the use of IoT in the DMIS process.

Step 2: The design of the system is made with the results of a comparison with an emphasis on the ease and availability of spare parts that are easily obtained.

Step 3: System design, Material Purchase, Manufacture, and Assembly are made with materials that have been budgeted.

Step 4: Design and manufacture of software to be used.

Step 5: Installation, Testing, and Testing of the results of the assembly and installation.

Step 6: System improvement and analysis of design results.

Step 7: Discussion and preparation of research reports

All stages are carried out based on data and test results of the maintenance of the die information system (DMIS) design that will be created and developed, each activity is carried out according to a predetermined schedule.

\subsection{Method of collecting data}

The method of data collection is done by collecting records of machine checking data records and comparing the data before and after using the DMIS system used for consideration and planning for information system design.

The data collection methods used are as follows:

1. Literature Study

This stage is the stage of collecting information and libraries needed to build a DMIS system, such as reading references via the internet regarding the required software and hardware equipment.

\section{Observation}

The method used to obtain data is by making observations in the field to find out the current state of the actual Dies Maintenance process and will be compared with existing data. 


\subsection{System Requirements Analysis}

In this study, the system requirements needed are:

1. Hardware (Hardware); The hardware used is PLC, Relay, Power Supply, Router access point, push-button, and Terminal Block.

2. Software (Software); The software used is easy builder Pro and Web Developer.

\subsection{System Planning}

The stages of system design carried out in this study are as follows:

1. Design of the Dies Maintenance Information System (DMIS).

2. Installation and configuration of hardware and software.

3. Implementation of the DMIS system.

4. Testing the DMIS system.

5. DMIS system documentation.

One of the software development methods is the waterfall (Sommerville, n.d.), the main stages of the waterfall model directly reflect the basic development activities. There are 5 stages in the waterfall model, namely requirements analysis and definition, system and software design, implementation and unit testing, integration, and system testing, and operation and maintenance. Details of the method as in Figure 3.

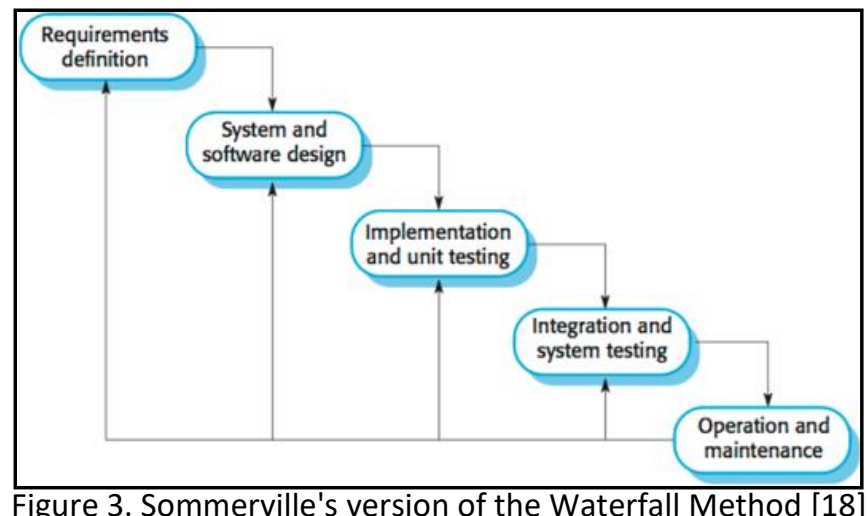

The stages of the waterfall method are as follows:

1. Requirements Analysis and Definition

In this system planning phase, we must first plan what project we will make, or in other words we must define the problem to be solved. This includes the stages of determining the features, constraints, and objectives of the system through consultation with system users. All of these will be defined in detail and serve as system specifications.

2. System and Software Design

In this stage, a system architecture will be formed based on the requirements that have been set and also identify and describe the basic abstractions of the software system and its relationships. In this phase, the design of the system will be carried out before coding. This stage aims to provide an overview of what must be done and how it will look. This stage helps in specifying hardware and system requirements and defines the overall system architecture.

3. Implementation and Unit Testing

At this stage, the results of the software design will be realized as a set of programs or program units. Software development is broken down into small modules which will be combined in the next stage. Each unit will be tested whether it meets its specifications. 
4. Integration and System Testing

In this stage, each program unit will be integrated and tested as a complete system to ensure the system meets the existing requirements and testing is carried out to find out whether the software made is following its design and there are still errors or not. After that, the system will be sent to the system user.

5. Operation and Maintenance

In the maintenance phase, the finished software is run and maintenance is carried out. Maintenance includes fixing errors that were not found in the previous step. The application development in this study only reached the integration and testing stage.

\subsection{Topology Design and DMIS System Concept}

The following is a system topology design that will be built as shown in the following figure 4.

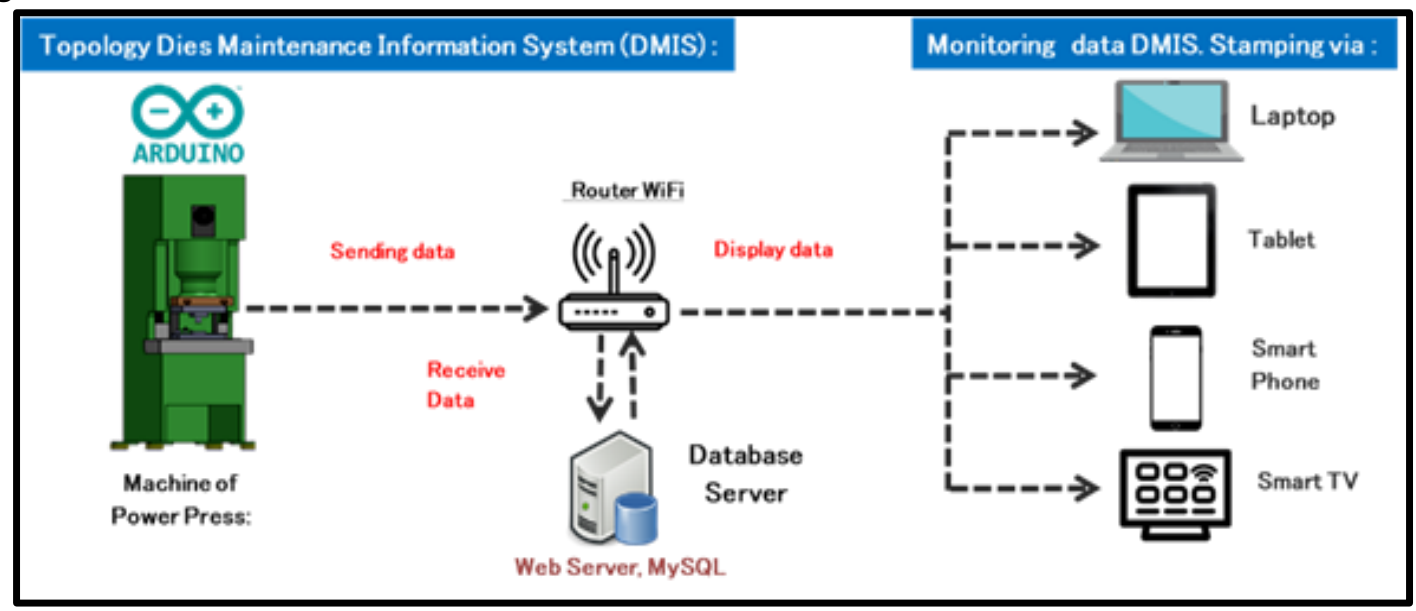

Figure 4. Topology of Dies Maintenance Information System (DMIS)

Figure 4 shows that the control panel will be installed on the DMIS control panel. Then the DMIS Control Panel will send the status to the machine panel, and the status will be forwarded to the database on the PLC through the intermediary access point. After that, the data in the PLC and the indicator panel will be processed into DMIS visual data by the developer and then the plan can be monitored on various platforms such as smartphones, Tablet/Android, PC, Laptop/Notebook and Smart TV.

\section{RESULTS AND DISCUSSION}

\subsection{Configuration of DMIS}

In Figure 5, there is 1 DMIS Hardware Panel unit installed in the Dies Keeper Area which is used to receive input status and send information from the Stamping Press Machine Panel components such as Machine Stops, Operations, and dies replacement needs through real-time and online access points. 


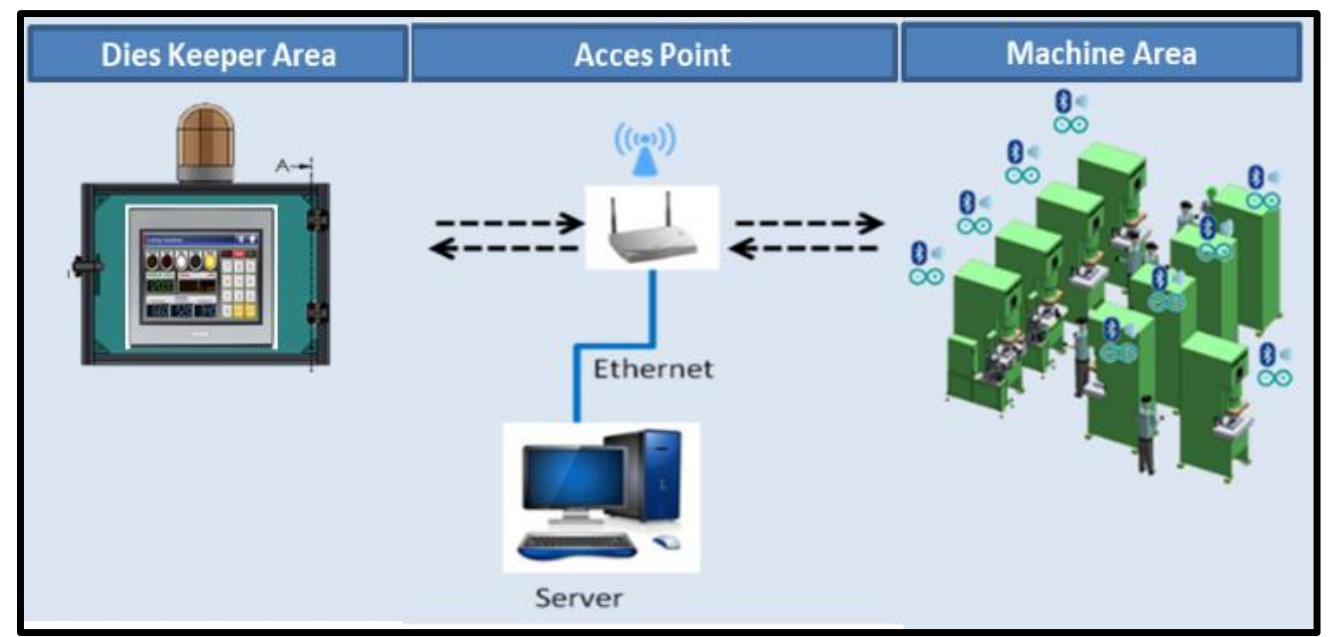

Figure 5. DMIS Panel Hardware Unit

Figure 6 shows the DMIS Control Panel configuration process to communicate with the Stamping Press Machine Panel and the input signal is sent to the Access Point to be accessed via smart devices, the production machine process inputs a replacement request through an indicator light to be displayed on the DMIS via the Access Point to be sent. to monitoring devices on various platforms to monitor the state of the production process in real-time.

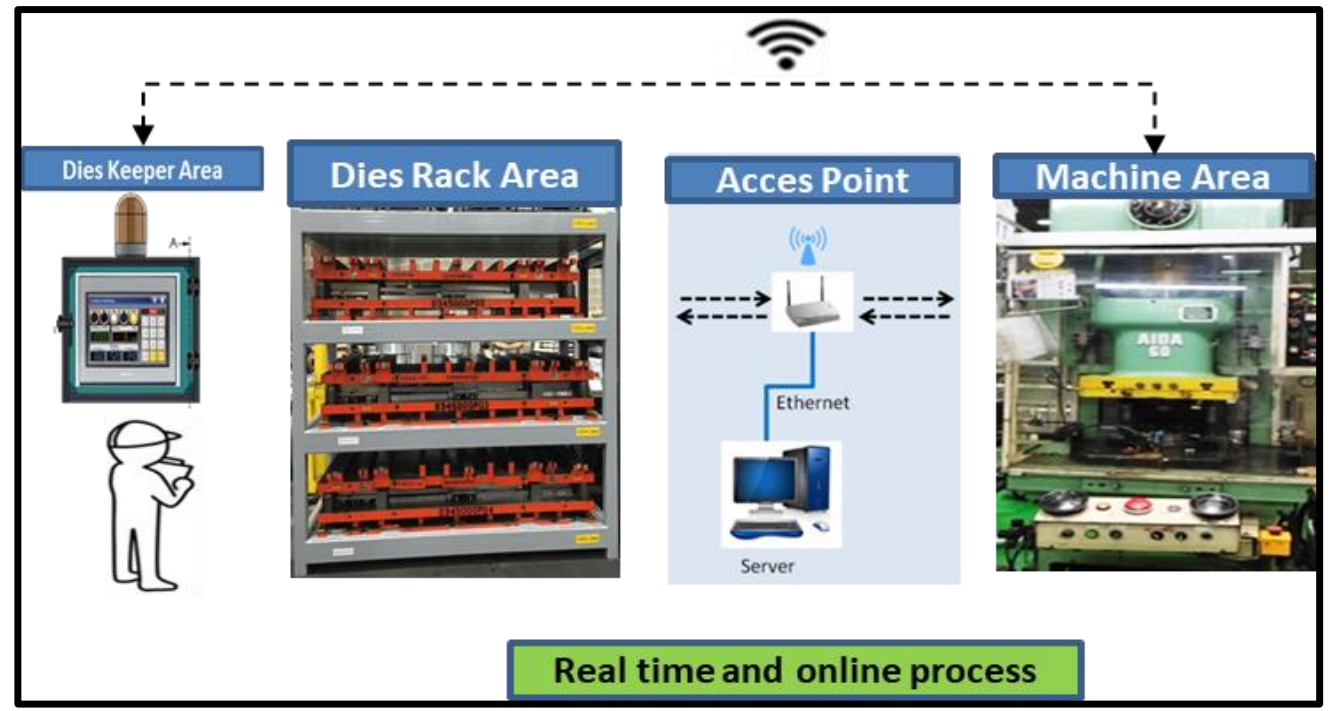

Figure 6. DMIS Control Panel Configuration

\subsection{Manufacture Electric Drawing Dies Maintenance Information System (DMIS)}

Figure 7 describes the wiring design for the maintenance of the die information system that is connected and connected to several hardware components, cable terminals, electrical supply, Arduino Wemos, indicator lights, HMI Touch panels, and other supporting components in one control panel. 


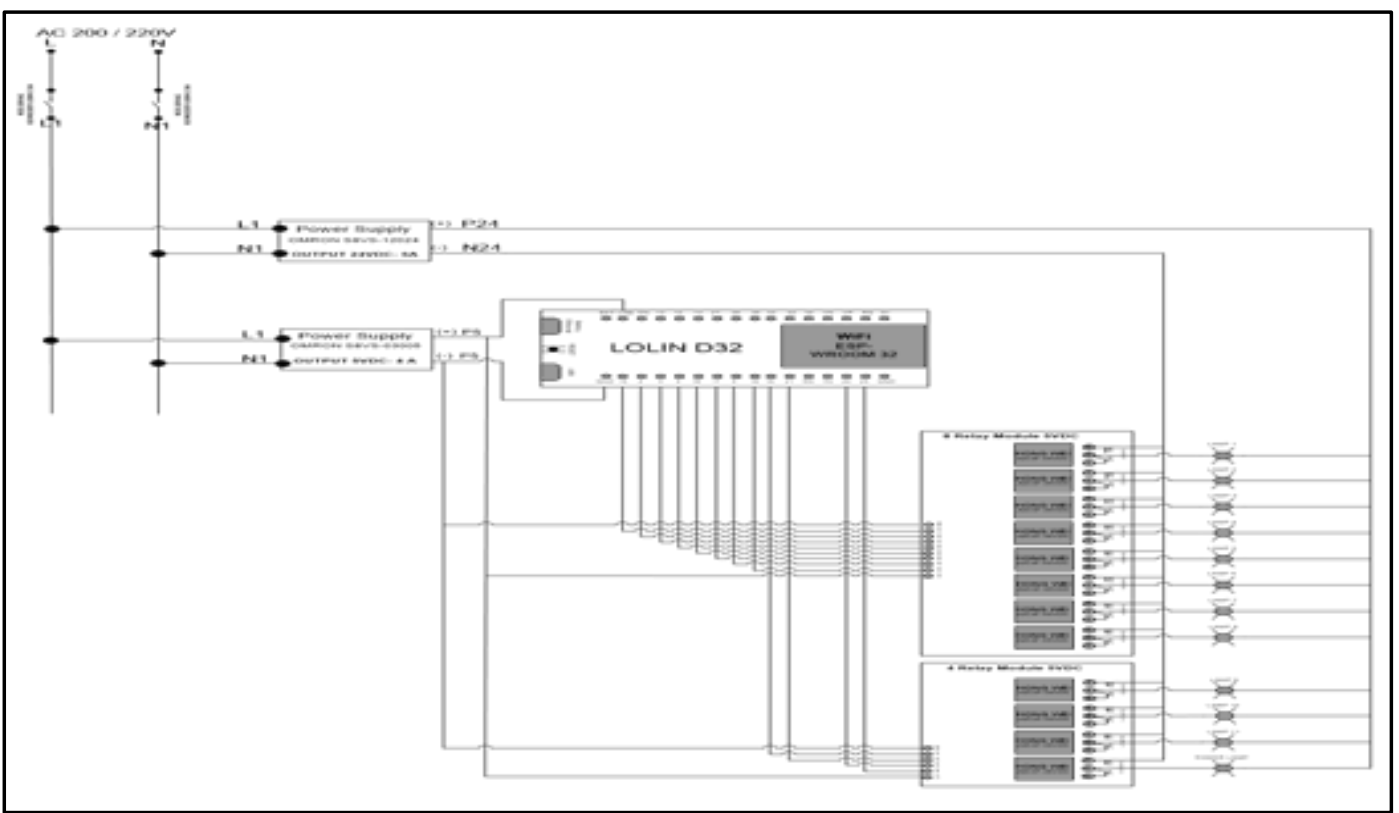

Figure 7. DMIS Wiring Diagram Design

The concept of the Dies Maintenance Information system panel design can be seen in Figure 8, the control panel box using a simple and transparent design for the placement of the $\mathrm{HMI}$ touch panel can be applied so that it is easier to monitor for abnormalities during the production process.

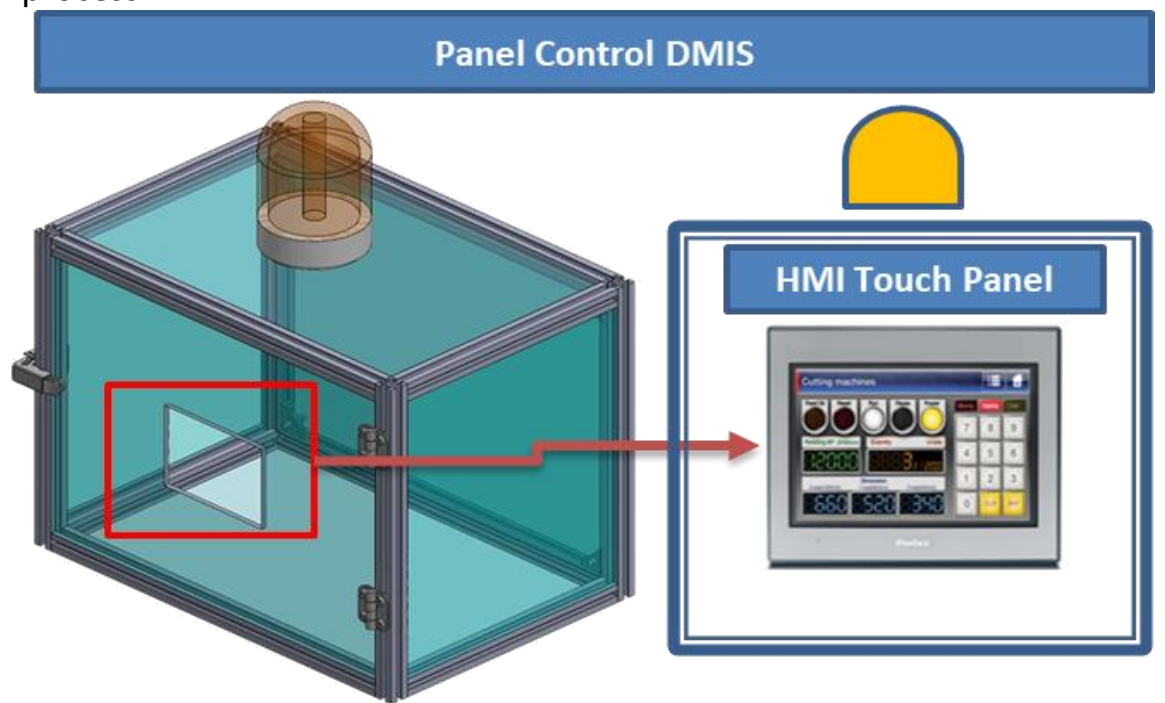

Figure 8. Control Panel DMIS HMI Touch Panel

\subsection{Manufacture Dies Program Maintenance Information System (DMIS)}

The application and installation script for Arduino for LOLIN D32 as a Server can be seen briefly in Figure 9. 


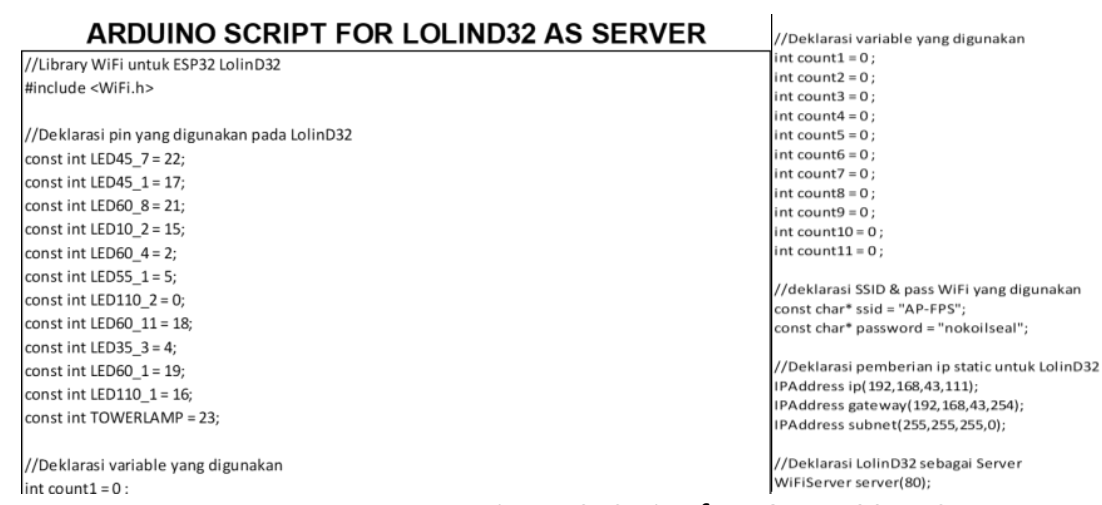

Figure 9. Script for LOLIND32 as SERVER

The application and installation script for the Arduino Wemos ESP8266 as a Client can be seen briefly in Figure 10.

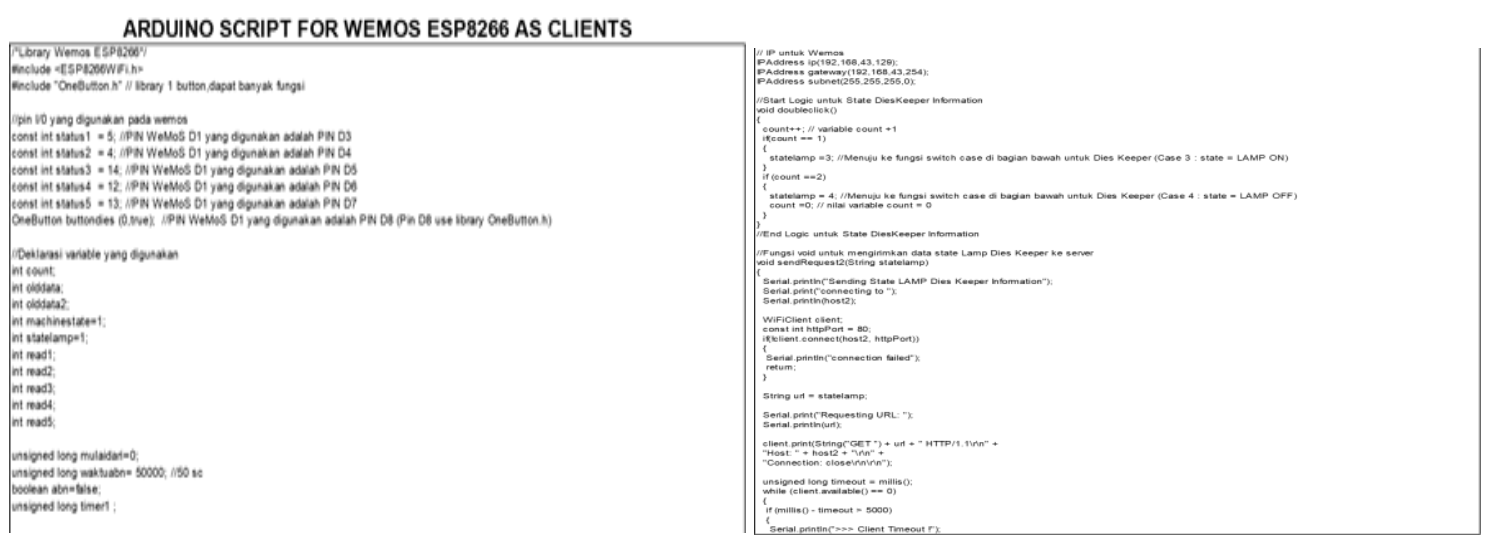

Figure 10. Script For Wemos ESP8266 Aa CLIENTS

The implementation of the DMIS application uses a Local Area Network (LAN) network using an access point. In Figure 11 is the process of setting wemos LOLIN D3 parameters and retrieving the necessary data, by turning on wemos then testing ping and $c=$ connection with WIFi nets as an access point to provide a wireless connection between signals from the machine area to the DMIS panel in the Dies Keeper Area, so that the connection process can take place with a monitoring plan and communication between parts, namely the production process and the maintenance officer.

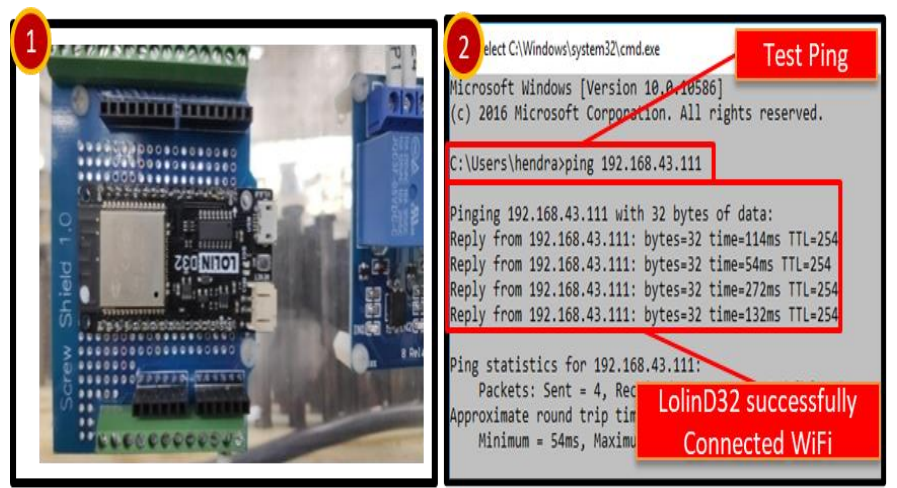

Figure 11. Setting Wemos LolinD32

Figure 12 shows the implementation and monitoring of testing between related sections, the control panel function can work well to provide real-time and online information, 
the indicator light and the sound of the buzzer can provide the necessary information when there is a demand and conditions in the production machine.

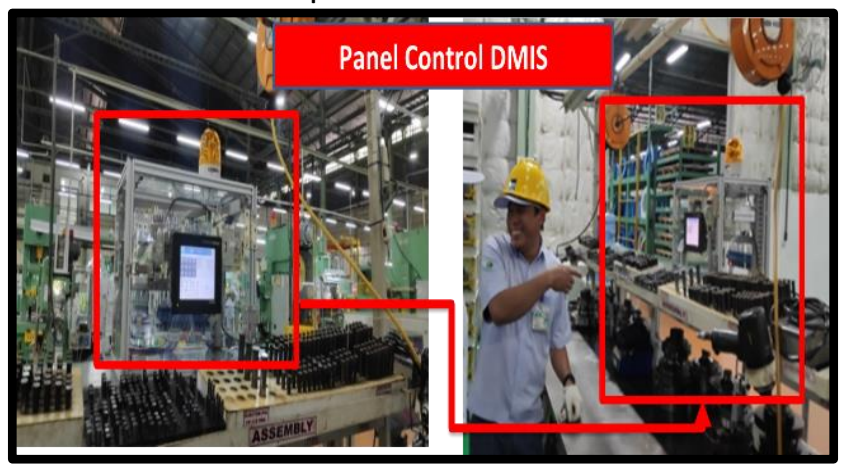

Figure 12. Control Panel DMIS After Implementation

\subsection{DMIS Development Results.}

The results of the Dies Maintenance Information System (DMIS) development, can be applied and monitored into smart devices / Smart devices for monitoring the dies maintenance process in the production process such as Smartphones, PCs, Notebooks, and Smart Monitors (TV) in real time \& on-line. details can be seen in Figure 13 as follows:

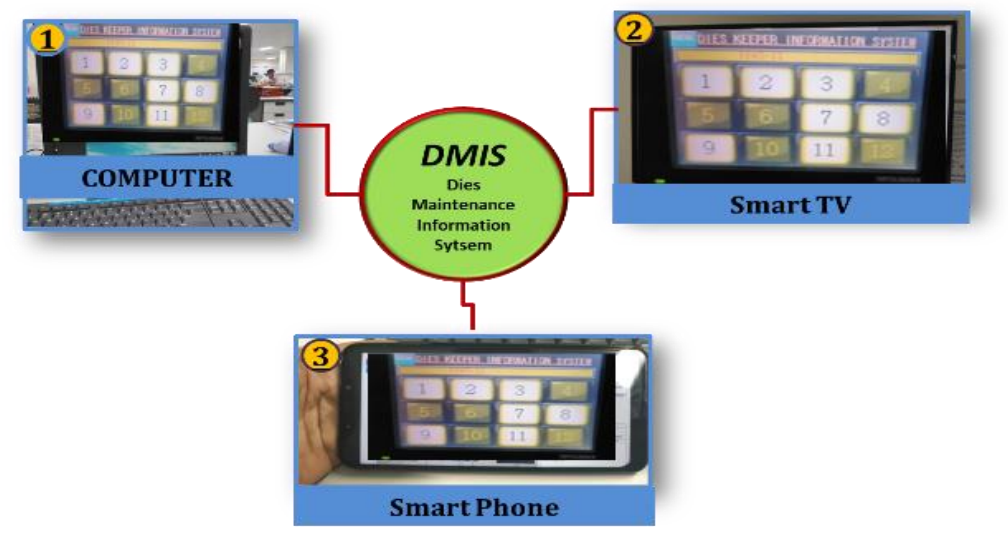

Figure 13. DMIS Development Results with Smart Devices

The use of DMIS can reduce the physical fatigue factor, making the trip to the machine to be checked no longer carried out because the use of information technology and telecommunications can be utilized optimally and supports work that has been done manually checking and recording into an automated process and is more accurate, avoiding data manipulation and information from operators in reporting the condition of the machines they use. Figure 14. Can see the comparison manual process with DMIS Process.
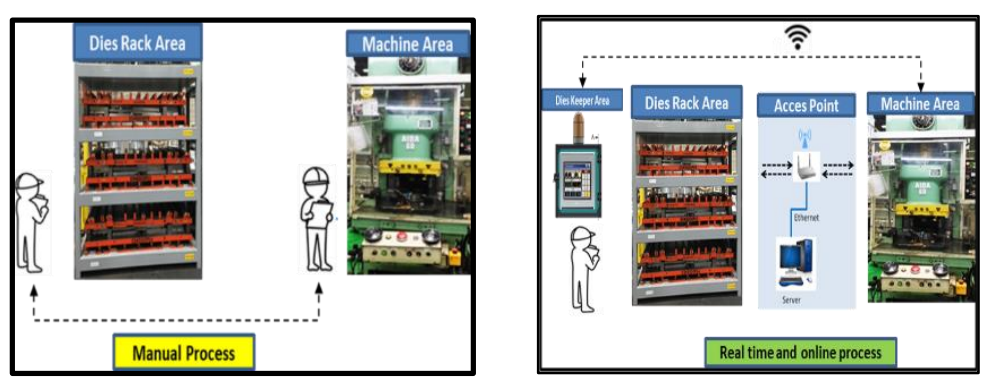

Figure 14. Comparison Manual Process with DMIS Process 
The research that has been carried out is an advantage for the company or organization so that the introduction of renewable technology can support the process of technological transformation from automation operations to the use of IloT according to the government's expectations in the application of making Indonesia towards smart factory/smart manufacturing can build Indonesia to apply IR.40, This research also make operators or employees in a company have the ability to upskill their ability to face the industrial era 4.0 because the use of digital technology to build digital manufacturing can be realized.

\section{CONCLUSION}

Based on the research that has been done, it can be concluded that the Dies Maintenance Information System (DMIS) application, can speed up obtaining data and information about the state of the production process and Dies part maintenance in real-time, making it easier for the user to monitor the production process without having to check and monitor the production process. come to the Machine Area, only by using a PC and a Smart Device for the user or operator, supervisor, manager, and the party who has the authority to check and supervise the production process remotely without having to come to the location every time so that DMIS can increase the effectiveness, the productivity of operator performance in operating and monitoring of machine processes in real-time and online.

\section{REFERENCES}

[1] H. H. B. Boyes, J. Cunningham dan T. Watson, "The Industrial Internet of things (IloT). An analysis framework," Comp. Ind, vol. 101, no. December 2017, pp. 1-12, 2018.

[2] K. Alexopoulos, S. Koukas, N. Boli dan D. Mourtzis, "Architecture and development of an Industrial Internet of Things framework for realizing services in Industrial Product-Service Systems," Procedia CIRP, vol. 72, p. 880-885, 2018.

[3] J. Arm, I. Vesely, Z. Bradac, F. Zezulka, P. Marcon dan T. Benesl, "Communication Systems for Industry 4.0 and the IIoT," IFAC-PapersOnLine, vol. 51, no. 6, p. 150-155, 2018.

[4] H. Ab-Samat, W. Liau, W. Yap, S. Kamaruddin, H. Tan dan P. Kehoe, "Implementation of Autonomous Maintenance in Semiconductor Industry: A Case Study," Adv. Mater. Res. , Vol. \%1 dari \%2591-593, no. November 2012, pp. 708-711, 2012.

[5] A. Kurhade, "Review on poka-yoke: a technique to prevent defects," International journal of engineering sciences \& research technology, vol. 9655, no. 11, p. 652-659, 2015.

[6] R. Hasanah, "Reliability-Centered Maintenance (RCM) Evaluation in the Industry Application, Case Study: Fertilizer Company, Indonesia," J. PASTI, vol. X, no. 1, p. 8-14, 2011.

[7] R. A. S. K. a. I. A. A. C. S. Min, "Development of autonomous maintenance implementation framework for semiconductor industries," Int. J. Ind. Syst. Eng, vol. 9, no. 3, pp. 268-297, 2011.

[8] P. S. Patil, S. P. Parit dan Y. Burali, "Review Paper On "Poka-Yoke: The Revolutionary Idea In Total Productive Management"," Research Inventory: International Journal Of Engineering And Science, vol. 2, no. 4, p. 19-24, 2013.

[9] V. Shenoy, "Error proofing : Effective tool for output efficiency," Int. J. Eng. Res. Mod. Educ., vol. 1, no. 1, p. 504-507, 2016. 
[10] M. A. M. U. S. I. Prastowo, "Human Machine Interface ( Hmi ) Berbasis Android Untuk Monitoring Dan Kendali Sistem Catu Daya," dalam e-Proceeding of Engineering, Bandung, 2015.

[11] R. HuUse the "Insert Citation" button to add citations to this document. Use the "Insert Citation" button to add citations to this document. daya, "Pengembangan Perangkat Lunak HMI/Scada Mandiri pada Lingkungan Networked Control Systems," dalam 6th IRWNS, Bandung, 2015.

[12] M. S. Reis, "A Systematic Framework for Assessing the Quality of Information in DataDriven Applications for the Industry 4.0," IFAC-PapersOnLine, vol. 51, no. 18, p. 43-48, 2018.

[13] G. Wiranto, G. Mambu, Hiskia, I. Hermida dan S. Widodo, "Design of Online Data Measurement and Automatic Sampling System for Continuous Water Quality Monitoring," dalam Proceeding of Conference on Mechatronic and Automation, Beijing, China, 2015.

[14] T. Budioko, "Sistem Monitoring Suhu Jarak Jauh Berbasis Internet of Things Menggunakan Protokol MQTT," dalam Prosiding Seminar Nasional Riset Teknologi Informasi 2016, Yogyakarta, 2016.

[15] N. Khatri, A. Sharma, K. Khatri dan G. Sharma, "An loT-Based Innovative eal-Time pH Monitoring and Control of Municipal Wastewater for Agriculture and Gardening," dalam Proceedings of First International Conference on Smart System, Innovations, and Computing, Jaipur, India, 2017.

[16] A. Widya dan H. Syaputra, "Pengembangan Aplikasi Machine Monitoring System (MMS) Berbasis Teknologi loT Wemos D1 dan Raspberry-Pi," dalam Call Paper Seminar Nasional Sistem Informatika dan Keamanan Siber, Jakarta, 2018.

[17] K. Rishitha dan S. Ullas, "IoT based Automation in Domestic Sewage Treatment Plant to Optimize Water Quality and Power Consumption," dalam Proceedings of the Third International Conference on Computing Methodologies and Communication, Erode, India, 2019.

[18] Sommerville, Software Engineering : Rekayasa Perangkat Lunak Edisi 6, Jakarta: Airlangga, 2011.

[19] Zakaria Yahouni, Nasser Mebarki. A new HMI scheduling model was implemented on a real manufacturing scheduling system. 7th workshop on Service-Orientation in Holonic and Multi-agent manufacturing (SOHOMA'2017), Oct 2017, Nantes, France. <hal01710260> 